\title{
Effectiveness of Prefabricated House Industry's Marketing Activities and Turkish Consumers' Buying Intentions towards Prefabricated Houses
}

\author{
Fahri Apaydın \\ Faculty of Economics and Administrative Sciences, Yalova University \\ Safranyolu, 77100, Yalova, Turkey \\ Tel: 90-216-814-9932Ｅ-mail: apaydin@yalova.edu.tr
}

Received: August 3, 2011

Accepted: August 30, $2011 \quad$ Published: October 1, 2011

doi:10.5539/ass.v7n10p267

URL: http://dx.doi.org/10.5539/ass.v7n10p267

\begin{abstract}
Prefabricated house industry might be considered as being at the stage of birth in Turkey and the consumer demand for this product category seems sluggish owing to some reasons. This empirical study explores some possible reasons of the low demand rates for prefabricated houses and data was gathered via an online survey in Turkey and some statistical analyses were conducted using SPSS statistical program. This paper also provides a cognitive framework to understand the consumer buying dimensions of prefabricated houses. The results reveal that marketing communication tools are not being used sufficiently, and thus marketing communications are not being held effectively by prefabricated houses manufacturers. As a result, consumers lack some significant information related with the attributes of the product, in this case prefabricated houses, they held misinformation about the product, so they do not develop desired buying intentions about this product category.
\end{abstract}

Keywords: Marketing Communication, Prefabricated House, Buying Intentions

\section{Introduction}

Prefabricated houses, which are also called manufactured houses, prefab houses, or modular houses in the industry (Expressmodular.com) are units of houses manufactured in large factories, and then transported to the site where they can be put ready for transfer to another location or mounted on the ground through masonry groundwork.

Although many earthquakes, which occurred so many times in history, have caused devastations almost in all areas within Turkish society, killed many people and resulted in many casualties, and several big magnitude ones are expected in the near future, prefabricated industry which possesses high market potential because of its high resistance to earthquakes has not flourished in Turkey due to the low demand. That prefabricated house industry seems to fail to create satisfactory demand for their products offer a huge area of research for academicians.

Due to increases in population and the threat of earthquakes, it is observed that need for new housing kind is an urgent issue that society should address efficiently, rapidly, and in a cheap way. The potential benefits of innovative prefabricated houses, also may be referred as mass housing, should be explained in order to overcome Turkish people's resistance to pre-fabricated housing. Changing attitudes of Turkish people is highly imperative in order for this industry to gain market share.

Standardized and pre-assembled houses have been successful for housing the people in a large number of prominent projects within a range of different situations. For example, people after 19 August earthquake in Turkey, a number of social housing projects were effectively and rapidly used temporally. On the other hand, privately and permanently owned prefabricated houses have admittedly been less practiced as they are presumed not to a have flexibility in design, room size and fittings until recently. However, currently available fabrication methods have been so improved that they own the potential to address the concerns of consumers, and thus show great potential for the future.

While many academic researches have been conducted about so many product categories, it has been apparent after a literature review that prefabricated house industry has not received enough researches, even though 
housing and protection from disasters are the basic needs of all human beings as supported in "Maslow's hierarchy of needs" (Solomon, 2010; Bazerman, 2001). Moreover, this industry thanks to developments in technology is now able to create and develop so many high-tech products in this product category which will satisfy the needs of consumers.

\section{Literature Review}

\subsection{Prefabricated Houses as a Consumption Good}

"Standardization and pre-assembly within construction industry has been proven to be successful in some projects including Hong Kong airport and much modern hotel construction" (Craig et. al., 2000). The importance of modular construction using a range of materials is also gaining importance and will continue to do so. Vale (1996) mentioned the importance of standard houses supports as did Lethaby in 1911. He said that "businessmen should target to manufacture houses as efficient as a bicycle, which was supported by who pointed out standardized houses". Laing et. al. (2001) claims that standardizing the construction process can create value for the consumers, which is one of the essential goals of marketers. For example, reducing construction period, optimum cost and high quality can be achieved with mass production of houses. Moreover, user satisfaction (which deserves future academic researches) and ease of maintenance and replacement all indicate that standardization and prefabrication bear significant potential for the future. The current demand, though far from being satisfactory, for prefabricated houses certainly points toward the need for such a production method to be applied. Standardization in this product category is not a barrier to produce generic, customer-specific, supplier led or project-specific prefabricated house. Craig et. al., (2000) and Sparksman et al., (1999) suggest that "prefabrication can take a number of various forms and the term can refer to components, sub-assemblies, volumetric pre-assembly and modular building".

Livesey (1983) categorizes innovation according to whether it involves the development of new products by either new or established techniques or the introduction of new processes for producing an established product in an industry. "The later fundamentally involves improvements in the technical efficiency of a production process" (Barlow, 1999). Prefabricated houses might be included in both categories in Turkish market as they are new to Turkish consumers and also the production process is not widely utilized.

Koklic \& Vida (2009) suggest that "prefabricated house purchasing is a high-involvement and emotionally charged products whose decision making process involves a lot of time, effort, and participants". Consumers take psychological and social factors into consideration as well as rational factors when making a decision and this makes the decision process complex. They define this type of purchase as "strategic decision making process which includes high involvement in the process; long-term commitment of resources; truncated budget available for other goods and services". Prefabricated houses are included in the durable goods category, and thus buying process which consumers go through resembles other durable goods' buying process (Punj \& Brookes, 2002). So examining the buying process of durable goods will usher the marketers how consumers make decisions related with this type of product.

Consumers express themselves with the goods they use, which indicates that goods consumers use function as a self-expressive tool. Likewise, the house in which people live demonstrates the human self-concept and personal identity (Koklic \& Vida, 2009; Grewal et. al., 2004; Gibler \& Nelson, 2003). The industry knowing this should design and develop prefabricated houses which will fit the personal values of consumers.

As price is used as an indicator of quality by consumers, prefabricated houses being less costly than traditional house might be perceived as less quality (Cooke \& Friedman, 2001). This notion might be overcome with well-designed and comprehensive marketing communication activities aimed at improving the image of the product. Another issue to be to be aware of is related with the manufacturing and attributes of prefabricated houses. People are concerned with sustainability and environmental and social values in the long run for almost all goods they purchase nowadays. Thus, Craig et. al. (2000) suggest that "it is vital that a long term perspective be taken and that the significant needs for flexibility, maintenance, and eventual disposal or re-use problem and solved at the design stage".

Quality is another concern with prefabricated houses. How consumers see prefabricated houses is really a matter that should be considered by the manufacturers. Unfortunately prefabricated house are thought to have poor quality when compared to the classic houses. Thus, manufacturers should understand the quality perception of the consumers related with this product category (Brucks et. al., 2000; Main, 1994). Therefore, "to understand market-driven quality, firms must learn how people perceive and evaluate quality instead of relying on firm-driven objective measures of quality" (Brucks et. al., 2000), so firms should explore what consumers value in this product category. 
Communication is a widely used tool to create prestige of goods in almost every product category. Through communication marketers develop and improve the prestige of the goods which of course needs to be supported with visible inherent characteristics and appearance of prefabricated houses. Furthermore, prestige is also related with consumers' social status and it fulfills a symbolic need (Brucks et. al., 2000). This product type seems to have low prestige among Turkish consumers due to the factors aforementioned. Park et. al. (1986) "make a definition of symbolic needs as desires for products that fulfill internally formed needs for self-enhancement, role position, group membership, or self-identification". The prefabricated industry should gain an insight about the image of this product which is considered poor among the consumers and develop marketing programs to enhance it with communication tools.

\subsection{Effects of Marketing Communications}

Marketing communication is the attempt of marketers to persuade consumers by providing them information and using other tools such as sales promotion, etc. To develop an effective marketing communication, marketers should be aware of the process that takes place during communication. In this process, "persuading, informing, listening, and answering" occurs in a mixed way (Duncan \& Moriarty, 1998; Andersen, 2001). In order to understand and meet individual demands of consumers, communication should be done effectively and continously.

Consumers need information the source of which can be internal (memory) or external (environment) to use in their decision process. Researchers suggest that "the search for information is affected by factors such as situational determinants, product determinants, and consumer characteristics". Marketing communication as well as experience, distribution, and individual goals, and related factors impact knowledge structure of consumers, and thus affect the decision process of consumers (Koklic \& Vida, 2009). A significant step in the decision process is the evaluation of alternatives, which involves detailed information for such a high-involvement product, which buyers have high level of interest. Buyers' specific goals, his/her motivation, involvement level, product knowledge, income level and similarities among alternatives are some of the factors that play an important role in the evaluation step (Hawkins et. al., 2003). Thus, manufacturers bearing this in mind should carry out efficient marketing communications and inform the consumers without as less knowledge gap as possible. Consumers purchasing high involvement goods typically search for product information until they feel ready to make a decision. Therefore, "from an information-processing perspective, a set of information cues" should be provided to help consumers to accelerate their decision making process by the prefabricated industry (Chu et. al., 2005).

Koklic \& Vida (2009) in their surveys found out that recommendations from friends or other house owners with experiences and information about the pefabricated house were very significant. Thus, word-of-mouth recommendations might play a significant role in buyers' or renters' information gathering and evaluation stages. "Word-of-mouth considered as an uncontrolled communication has high impact on the image of the product" (Grace, 2005). Therefore, the industry itself should develop integrated marketing communications using all available tools including word-of-mouth to maximize the effects of marketing communication.

In the marketing literature, some researchers explain marketing communication with AIDA model and prefabricated house makers should benefit from this model. This model suggests that attention, interest, desire, and action of consumers can be created with efficient marketing communications (Lagrosen, 2005). After processing information they receive, consumers make purchasing decisions depending on the benefits they will get from the goods (Alba \& Hutchinson, 1987). For this reason, seller or manufacturer-created product information may be more useful to consumers regarding more sophisticated products such as prefabricated houses (Livette, 2006). Thus, manufacturers should do marketing communication activities without relying on the third parties.

Marketing activities have the potential enhance the product image in case it creates "a more favorable behavioral response" to the any goods. Managerial efforts to promote the image of prefabricated houses will result in the establishment of positive associations about them and diminish the negative ones, which is slightly more difficult than the former. Therefore, to create, to manage, and to exploit image and reputation of prefabricated houses, manufacturers should be involved in marketing activities specifically marketing communications more (Yoo et. al., 2000).

Turkish consumers resist prefabricated houses because of to certain extent rational reasons. Economic considerations like the consumers in England play a great role in their house purchasing decisions (Craig et. al., 2000; Laing et. al., 2001). Houses in Turkey are seen as a means of investment rather than merely a consumer good. Based on the observations, it was seen that consumers are holding the idea that prefabricated houses do not 
have second hand market, thus they are not mostly considered as an investment tool. However, in Turkey houses are considered as an investment tool because Turkey is a growing market and the value of real estate goes up exponentially.

"Prefabricated industry in the United States, applied various marketing communication programs to increase the demand for prefabricated houses during the 1900s. The firms gave the message of feeling fashionable, modern, and secure within the context of familiar-feeling environment. As a result, the industry was successful with the marketing communication and able to achieve great improvements in the sales" (Cooke \& Friedman, 2001). Similar marketing activities might be carried out in Turkey to increase the demand for this product.

"After the midst of 70s, the prefabricated house industry in Japan applied an integrated marketing program to change the inferior image of industrialized houses prevalent in the industry's early years. The 'mass production' of housing was the key factor in creating monotonous, boxy units which the public subsequently regarded as being of 'low quality'. Instead of tailoring their products to meet the demand for affordable homes, Japanese housing manufacturers satisfy the demands for value-added quality home by adhering to higher standards" (Noguchi, 2003). Likewise, manufacturers in Turkey should focus on the quality attribute of the product and affect the quality perception of consumers.

\subsection{Purchasing Intentions}

Purchasing intentions are highly related with the attitudes of consumers. Thus, creating positive attitudes will affect the purchasing intentions of consumers. To affect consumers' attitudes they should be provided information and made like the prefabricated house. "Constructive theory gives a well established framework for understanding what factors might be effective on consumers' attitudes" and the assumptions of this theory are (Bettman et. al., 1998):

(1) Choice among options depends critically on the goals of the decision maker

(2) Choice among options depends on the complexity of the decision task

(3) Choice among options is context dependent

(4) Choice among options depends on how one is asked

(5) Choice among options depends on how the choice set is represented (framed) or displayed

This theory might represent the basics of the decision making process of consumers when they are purchasing a house. The factors that are effective in consumers' decisions should be well understood by the prefabricated house industry actors and marketing programs should be developed accordingly. Buying a house is a critical task for consumers as it requires a lot of money and impacts social status of the consumers in the society. The decision in nature is extremely complex and usually not repeated very frequently, thus marketing communication might play a significant role by providing necessary information to consumers.

In cases, Hansen (2005) suggests that "when people are highly involved in the decision making process, they are likely to engage in a more extensive internal and/or external information search to reduce the risk of making a choice with undesirable results". The researcher puts forward that in such cases gaining information, conducting an evaluation, and comparisons of products to make a decision requires high level of cognitive efforts. Thus, when making a decision about a durable and expensive product such as prefabricated houses, consumers are needed to be provided with an optimum level of information (Bagozzi et al., 1999; Rao \& Monroe, 1989). House purchasing involves emotional evaluation as well for most of the customers, so manufacturers should focus on this issue in their marketing activities.

"The cognitive response approach suggests that attitude changes depend on both the amount and direction of thought generated by consumers" (Brinol et. al., 2004). Thus to change the attitudes of consumers towards prefabricated houses, manufacturers need to expose consumers with more positive information about the product via marketing communications.

\subsection{Name Effect}

"There are many potential attitudinal barriers to standardization and pre-fabrication of houses" some of which are thought to be based on the name of the product (Craig et. al., 2000). Olson (1977) and Dodds (1991) suggested that consumers use various cues to infer product quality and "these cues include extrinsic cues that are not directly related to performance of the product and intrinsic cues that are achieved from directly from the physical product itself'. Some examples of extrinsic cues are price, name of the product, and manufacturer name (Rao \& Monroe, 1989). The impact of name appears to serve as a cue for quality as it reminds some associations linked to the product (Olson 1977; Stokes 1985). Mazursky \& Jacoby's (1985) findings support this belief as 
well, indicating the importance of the name of the product. Prefabricated houses have been used in various programs such as sheltering the victims of earthquakes, sheltering the homeless, and sheltering the poor, thus some negative associations might have been developed in the minds of consumers related with this product. Therefore, as the name "prefabricated house" denotes some negative meanings, it is believed manufacturers should use a different name for this product to diminish possible negative associations.

Based on the literature review and observations about the consumer behaviors, following hypotheses were developed to be tested in this research:

\section{H1: Consumers hold misconceptions about prefabricated houses.}

H2: Prefabricated house industry does not utilize marketing tools effectively.

H3: Consumers resist to prefabricated houses because they do not see them as an investment tool.

H4: Consumers perceive prefabricated houses of poor quality due to low prices.

H5: The name of the product, prefabricated house, extenuates the given messages through marketing communications about the prefabricated houses.

\section{Methodology}

First of all, a broad literature review was done in academic journals and it was observed that very few researches, most of which are old dated, had been conducted on this product category. A questionnaire was developed following the procedure detailed below. All the questionnaire items were developed in Likert-like scale at one end (1) completely disagree and at the other (5) completely agree. An online survey was conducted, and 107 responses were received, which was considered to be sufficient to carry out such a study having the potential to be the bases of further researchers. Descriptive statistics of respondents are indicated in Table 1.

Afterwards, a search was done on "Google.Com" about the manufacturers and distributors of prefabricated houses. Web sites that appeared on the first three pages of "Google.Com" were visited, and we noted down the common features that are claimed by the manufacturers to exist in prefabricated houses. These statements then were turned into 10 statements which appear below. By doing so it would be possible to observe the variance between what attributes the prefabricated houses were claimed to have by the actors of the industry and what consumers know about the product. Additional 3 statements were used in the questionnaire to understand possible misconceptions consumers hold about prefabricated houses. Moreover, in the literature review, it was found out that one of the main motivations for Turkish consumers is that they see houses as a significant tool of investment, so 3 more statements were developed to test it. Totally 16 items related with cognitive dimension of consumer attitude towards prefabricated houses were used in the questionnaire and they are as follows:

- Prefabricated houses are more resistant to earthquakes when compared to traditional houses.

- Prefabricated houses are more comfortable than traditional houses.

- Prefabricated houses are cheaper than traditional houses.

- Maintenance of prefabricated houses is easier than traditional houses.

- Prefabricated houses are more durable than traditional houses. (This is a reverse item as manufacturers say that prefabricated houses are less durable.)

- Interior design can be made in the way I want.

- Prefabricated houses are quicker to build than traditional houses.

- Prefabricated houses have better heat isolation than traditional houses.

- Prefabricated can be manufactured on any area and with any size.

- Prefabricated houses have better outlooks than traditional houses.

Speculated items in the questionnaire are:

- $\quad$ Prefabricated houses can be moved to another place.

- Renovation could be made in the interior side of the prefabricated houses after it is built.

- Prefabricated houses are more secure than traditional houses.

Items measuring how consumers see prefabricated houses as an investment:

- It is easy to find a tenant for prefabricated houses.

- It is easy to resell the prefabricated houses. 
- $\quad$ Prefabricated houses are a good alternative for investment.

The respondents were also asked the frequency of their exposure to the marketing communications they received from various tools (i.e. television, radio, internet, newspapers/magazines, billboards, and brochures/catalogues) done by actors of prefabricated industry. Intentional dimension of consumer attitudes toward prefabricated houses were measured with 6 items, three of which measured purchasing intention and three of which measured renting intention.

It is suggested in this study that consumers recall some negative associations due to the name of the product "prefabricated house" and they develop resistance to this product type. To understand, the nature of consumer resistance to prefabricated houses, name effect was explored by creating a scenario. In the scenario, respondents were told that a firm would launch a new product called "ready house". The attributes of "the new product" were almost the same with attributes of prefabricated houses. 6 Items developed to measure the purchasing intentions of people were also used to measure possible reactions of consumers to "new product". In the items instead of "prefabricated houses" "ready houses" were used.

The reliability of the scales are all above the accepted level 0.70 : Marketing communication, 0,83 ; prefabricated house using intention, 0,93; consumer knowledge about prefabricated houses, 0,82; ready house using intention, 0,90 .

\section{Results and Findings}

First, factor analysis was conducted to find out the consumer buying intention dimensions related with this product category (Table 2). Verimax rotation with Kaiser Normalization was applied to make explaining factors clearer. Factor loads and total explained variance $(64,14 \%)$ are indicated in the table and five factors seem to be the consumer buying intention dimensions which are called: investment tool (1), flexibility (2), quality (3), design (4), and efficiency (5). Being an investment tool seems to be the main driver of consumers when considering to buy a prefabricated house as its factor load is bigger than the other dimensions. Thus, manufacturers should refer to these dimensions when sending messages to consumers via communication tools.

Descriptive statistics and correlations among variables are indicated in Table 3. As it is seen in the table, respondents claim that they are not exposed to messages about prefabricated houses often. The mean of marketing communication is below the mid point (3). Thus, one can infer that manufacturers' of this product category do not carry out marketing communications to target consumers. The interesting finding of this research can be read in Table 3. Although the respondents claim that they are not exposed to messages about the prefabricated houses, most information they have about prefabricated houses seems very close to what manufacturers provide on the Internet. The reason of this possibly is consumers receive information about this house type not from manufacturers but form elsewhere (e.g. word-of-mouth, education, educational TV programs, etc.). That information about prefabricated houses is provided by third parties bears some risks for the manufacturers. The risk involves possible misconceptions about the prefabricated houses might be provided to the consumers. As a result, $\mathrm{H} 1$ is supported.

Regression analysis was conducted to see the effects of marketing communication and importance level of the prefabricated house buying behavior dimension on the dependent variable buying intention (Table 4). The model is significant at 0,001 level and explains $44 \%$ of the variance in the dependent variable, which is considerably high. $\mathrm{F}$ value in the regression model is 14,79 . In the model, marketing communication does not impact the dependent variable at all, which supports the idea that prefabricated manufacturers fail to do marketing communications effectively. Investment, efficiency, and appearance are the independent variables that have significant effect on the dependent variable. Their significance level is within the acceptable limits $(0,05)$. Being an investment tool seems the most effective variable in this model, which is in line with literature. However, efficiency, which consists of items measuring cheapness, easy to maintain, and quick to build, has negative effect (standardized coefficient is minus) on the dependent variable. This supports the suggestions of this paper so far. Flexibility is not significant in this model probably because the traditional houses are also perceived as flexible, so no difference is seen between them by the respondents. As a result $\mathrm{H} 2, \mathrm{H} 3$, and $\mathrm{H} 4$ are supported.

Some ANOVA analyses were conducted to see the significant difference between the groups in terms of their responses to prefabricated buying intention. First, it was tested whether sex was a determinant in considering prefabricated houses as an investment tool. Women see buying a prefabricated house as an investment tool more than men do. The mean difference between these groups are significant ( $\mathrm{sig}=0,06 ; \mathrm{F}$ value $=3,47$ ). However, it is a general trend in Turkey that women usually consider any kind of house as an investment tool, so the difference observed in this analysis may not be confined to just prefabricated houses. Then, it was tested whether age was a determinant in prefabricated house purchasing intention. Elder people have higher intention to buy or rent a prefabricated house than younger people. The mean value of elder people is higher, and the difference is significant (sig. $=0,01, \mathrm{~F}$ value $=3,32$ ). 
Paired sample t-test was carried out to test the name effect of prefabricated houses on consumers buying intention. Overall mean of "ready house" buying intentions was 3,37 and overall mean of prefabricated house buying intentions was 2,81 at the significance level of 0,001 and $t$-value was $-5,817$, which indicates that people have negative associations about prefabricated houses, so H5 is supported.

\section{Conclusion}

Prefabricated house market has high potential in Turkey; however, prefabricated house manufacturers can not benefit from it as they fail to create demand for this product category due to insufficient marketing communication activities. Furthermore, that consumers have respectively enough information about the product offers manufacturers the opportunity to create demand by using marketing tools. This research might be a base for further researches related with this product category since findings might usher both the academicians and manufacturers for further researches.

Some managerial implications of the results of the survey are discussed in this part. First of all, the main implication for managers is they need to develop efficient and effective marketing programs about this product type. It is obvious from the results that prefabricated industry disregards marketing activities. Another implication for managers is that segmentation is not done efficiently in this product type. That is why respondents might develop negative associations about even very high expensive products of prefabricated industry. What manufacturers need to do is to segment the market properly and develop and name the products accordingly. Also, although consumers seem to have considerable amount of information some of which is false, they do not demand prefabricated houses. This shows that actors in prefabricated industry fail to stimulate consumer demand. This finding necessitates more marketing communication about the product. The life period of this product seems to be considered as a weakness by Turkish consumers and it should be developed by the manufacturers as well.

Like other researches, this research bears some limitations one of which is the number of the response. The response number is rather low which is thought to possibly have some effects on the results of the analysis. However, as it is really difficult to make surveys, still the results give significant insights about prefabricated industry and attitudes of consumers towards this product type. Another limitation might be that this research was conducted on-line. Respondents probably are either well educated or information seeking people. Nevertheless, the results are valuable because that even well educated consumers have misconceptions about prefabricated houses is a good indicator of the insufficiency of marketing communications of prefabricated houses industry. Moreover, the name effect of the prefabricated house was measured based on a scenario, which might have created some unexpected bias among the respondents, but it can be said that it still reveals the linkages the respondents have in their minds with the name of the product which provides valuable opinion about the issue.

This research might be a base for further researches attracting the attention of academicians to this topic. While so many researches have been conducted related with other products, it is surprising that prefabricated houses which might be efficient, quick, and cheap solution to housing problem in most part of Turkey are explored insufficiently. Most of the topics about other products should be applied in doing researches about this product type as well. The results of survey reveal that consumers hold some misconceptions and have developed some negative associations about prefabricated houses. Thus, the nature of these associations and the sources and possible solutions to misconceptions consumers hold about this product offers academician a wide range of research area.

\section{References}

Alba, J.W. \& Hutchinson, J.W. (1987). Dimensions of Consumer Expertise. Journal of Consumer Research, 13 (March), 411-454. http://dx.doi.org/10.1086/209080

Andersen, B.W. (2001). The Analysis and design of pneumatic systems. New York: Krieger.

Bagozzi, R.P., Gopinath, M., \& Nyer, P.U. (1999). The Role of Emotions in Marketing. Journal of the Academy of Marketing Science. 27(2), 184-206. http://dx.doi.org/10.1177/0092070399272005

Barlow, J. (1999). From Craft Production to Mass Customization. Innovation Requirements for the UK Housebuilding Industry. Housing Studies, 14(1), 23-42. http://dx.doi.org/10.1080/02673039982984

Bazerman, M.H. (2001). Reflections and Reviews: Consumer Research for Consumers. Journal of Consumer Research, 27(4), 499.504.

Bettman, J.R., Luce, M.F., \& Payne, J.W. (1998). Constructive Consumer Choice Processes. Journal of Consumer Research, 25(December), 187-117. http://dx.doi.org/10.1086/209535

Brinol, P., Petty, R.E., \& Tormala, Z.E. (2004). Self-validation of Cognitive Responses to Advertisements. Journal of Consumer Research, 30(4), 559-574. 
Brucks, M., Zeithaml, V.A., \& Naylor, G. (2000). Price and Brand Name as Indicators of Quality Dimensions for Consumer Durables. Journal of the Academy of Marketing, 28, 359-374. http://dx.doi.org/10.1177/0092070300283005

Chu, W., Choi, B., \& Song, M.R. (2005). The Role of On-line Retailer Brand and Infomediary Reputation in Increasing Consumer Purchase Intention. International Journal of Electronic Commerce, 9(3), 115-127.

Cooke, A. \& Friedman, A. (2001). Ahead of their Time. Journal of Design History, 14(1), 53-70. http://dx.doi.org/10.1093/jdh/14.1.53

Craig, A., Laing, R., \& Edge, M. (2000). 21st Century: Cities, social life and sustainable development. 16th IAPS Conference, Paris, 4th-7th July, 161-169.

Dodds, W.B. (1991). In Search of Value: How Price and Store Name Information Influence Buyers' Product Perception. The Journal of Services Marketing, 5(3), 27-37. http://dx.doi.org/10.1108/08876049110035602

Duncan, T. \& Moriarty, S.E. (1998). A Communication-based Marketing Model for Managing Relationships. Journal of Marketing, 56(2), 1-13. http://dx.doi.org/10.2307/1252157

Expressmodular.com. [Online] Available: http://www.expressmodular.com/modular_construction.php (July 23, 2011)

Gibler, K.M., \& Nelson, S.L. (2003). Consumer Behavior Applications to Real Estate Education. Journal of Real Estate Practice and Education, 6(1), 63.89.

Grace, D. \& O'Cass, A. (2005). Examining the Effects of Service Brand Communications on Brand Evaluation. The Journal of Product and Brand Management, 14(2/3), 106-117. http://dx.doi.org/10.1108/10610420510592581

Grewal, R., Mehta, R., \& Kardes, F.R. (2004). The Timing of Repeat Purchases of Consumer Durable Goods: The Role of Functional Bases of Consumer Attitudes. Journal of Marketing Research, 41(1), 101-15. http://dx.doi.org/10.1509/jmkr.41.1.101.25090

Hansen, T. (2005). Perspectives on Consumer Decision Making: An Integrated Approach. Journal of Consumer Behavior, 4(6), 420-437. http://dx.doi.org/10.1002/cb.33

Hawkins, D.I., Best, R.J., \& Coney, K.A. (2003). Consumer behavior: Building marketing strategy. Madison, WI: Irwin McGraw-Hill.

Koklic, M.K. \& Vida, I. (2011). A Strategic Household Purchase: Consumer House Buying Behavior. Managing Global Transitions International Research Journal, 7(1), 74-96.

Lagrosen, S. (2005). Effects of the Internet on the Marketing Communication of Service Companies. Journal of Services Marketing, 9(2), 63-69. http://dx.doi.org/10.1108/08876040510591376

Laing, R., Craig, A., \& Edge, M. (2001). Prefabricated Housing: An assessment of cost, value and quality. Proceedings of the International Conference on Construction (Construction for tomorrow's city), Hong Kong, 19-21 June 1, 80-92.

Livesey, F. (1983). Economics for business decisions. Eastover, Plymouth and Philadelphia, Pa.: Macdonald and Evans

Livette, M. (2006). A marketing Perspective of Private Sector Retirement Housing and the Effectiveness of the Buyer Behavior of Its Purchasers. Property Management, 24(4), 383-396. http://dx.doi.org/10.1108/02637470610671613

Main, J. (1994). Quality wars. New York: Free Press.

Mazursky, D. \& Jacoby, J. (1985). Forming impressions of merchandise and service quality. In Perceived Quality. Eds. Jacoby, J. \& Olson, J. Lexington, MA: Lexington Books, 13-54.

Noguchi, M. (2003). Policy and Practice the Effect of the Quality-oriented Production Approach on the Delivery of Prefabricated Homes in Japan. Journal of Housing and the Built Environment, 18, 353-364. http://dx.doi.org/10.1023/B:JOHO.0000005759.07212.00

Olson, J.G. (1977). Price as an informational cue: Effects in product evaluation. In Consumer and industrial buying behavior. Eds., Woodside, A.G., Sheth, J.N., \& Bennet, P.D. New York: North Holland, 267-286.

Park, C.W., Bernard, J.J., \& Macinnis, D.J. (1986). Strategic Brand Concept-Image Management. Journal of Marketing, 50(October), 135-145. http://dx.doi.org/10.2307/1251291

Punj, G.N. \& Brookes, R. (2002). The Influence of Pre-decisional Constraints on Information Search and Consideration Set Formation in New Automobile Purchases. International Journal of Research in Marketing, 19(4), 383-400. http://dx.doi.org/10.1016/S0167-8116(02)00100-3 
Rao, A. \& Monroe, K.B. (1989). The Effect of Price, Brand Name, and Store Name on Buyers' Perceptions of Product Quality: An integrative Review. Journal of Marketing Research, 26, 351-357. http://dx.doi.org/10.2307/3172907

Sparksman, G., Groak, S., Gibb, A., \& Neale, R. (1999). Standardization and preassembly: adding value to construction projects. CIRIA Report, 176.

Solomon, M. R. (2010). Consumer behavior (9th ed.). New York: Prentice Hall.

Stokes, R.C. (1985). The effect of price, package design, and brand familiarity on perceived quality. In Perceived quality. Eds. Jacoby, J. \& Olson, J. Lexington, MA: Lexington Press, 233-246.

Vale, B. (1996). Prefabs: A history of the UK temporary housing programme. London: E \& FN Spon, 78.

Yoo, B., Donthu, N., \& Lee, S. (2000). An Examination of Selected Marketing Mix Elements and Brand Equity. Journal of the Academy of Marketing Science, 28(2), 195-211. http://dx.doi.org/10.1177/0092070300282002

Table 1. Descriptive statistics of respondents

\begin{tabular}{llll} 
& & Frequency & Percent \\
\hline \multirow{4}{*}{ Gender } & Male & 53.00 & 49.53 \\
& Female & 53.00 & 49.53 \\
& Total & 106.00 & 99.07 \\
& Missing & 1.00 & 0.93 \\
\hline value & 23 and & 27.00 & 25.23 \\
& below & 46.00 & 42.99 \\
Age & $24-30$ & 26.00 & 24.30 \\
& $31-40$ & 4.00 & 3.74 \\
& $41-50$ & 2.00 & 1.87 \\
& 51 and above & 98.13 \\
& Total & 105.00 & 1.87 \\
\hline \hline & Missing & 2.00 & \\
value & &
\end{tabular}

Table 2. Factor analysis of the items about prefabricated houses

\begin{tabular}{|c|c|c|c|c|c|}
\hline \multirow[b]{2}{*}{ Items } & \multicolumn{5}{|c|}{ Factors } \\
\hline & Investment & \begin{tabular}{|c|} 
Flexibilit \\
$y$
\end{tabular} & $\begin{array}{c}\text { Qualit } \\
y\end{array}$ & $\begin{array}{c}\text { Efficienc } \\
y\end{array}$ & $\begin{array}{c}\text { Appearanc } \\
e\end{array}$ \\
\hline selling capacity &, 850 & & & & \\
\hline renting capacity & ,848 & & & & \\
\hline investment tool & ,593 & & & & \\
\hline comfort & ,577 & & & & \\
\hline $\begin{array}{l}\text { renovating internal } \\
\text { design }\end{array}$ & &, 833 & & & \\
\hline removability & &, 735 & & & \\
\hline different size options & &, 550 & & & \\
\hline long life & & & ,806 & & \\
\hline heat isolation & & &, 630 & & \\
\hline security for robberies & & &, 592 & & \\
\hline $\begin{array}{l}\text { resistance to } \\
\text { earthquake }\end{array}$ & & & ,559 & & \\
\hline cheapness & & & & ,791 & \\
\hline maintenance & & & & ,734 & \\
\hline fast to build & & & &, 512 & \\
\hline outlook & & & & & ,756 \\
\hline $\begin{array}{l}\text { flexible internal } \\
\text { design }\end{array}$ & & & & & ,488 \\
\hline Factor Loads & 14,744 & 12,765 & 12,667 & 12,416 & 11,587 \\
\hline Total Expl. Var. & & & 64,179 & & \\
\hline
\end{tabular}


Table 3. Descriptive statistics and correlations among variables

\begin{tabular}{|c|c|c|c|c|c|c|c|c|c|c|}
\hline Variables & $\begin{array}{c}\text { Mea } \\
\mathbf{n}\end{array}$ & $\begin{array}{c}\text { Std. } \\
\text { Dev } \\
\text {. }\end{array}$ & 1 & 2 & 3 & 4 & 5 & 6 & 7 & 8 \\
\hline 1 communication & 1,90 &, 80 & 1 & & & & & & & \\
\hline 2 investment & 2,59 &, 71 & ${ }_{*}, 31^{*}$ & 1 & & & & & & \\
\hline 3 flexibility & 3,70 & ,67 & ,13 &, $27^{*}$ & 1 & & & & & \\
\hline 4 quality & 3,15 & ,65 & ,09 & ${ }_{*}, 38^{*}$ & ${ }_{*}^{3}, 39^{*}$ & 1 & & & & \\
\hline 5 efficiency & 3,91 & ,64 & ,09 &, 11 & $39^{*}$ &, 15 & 1 & & & \\
\hline 6 appearance & 3,50 &, 86 &, $35^{*}$ &, $40^{*}$ & ${ }_{*}^{, 50 *}$ &, $30^{*}$ & ${ }_{*} 40^{*}$ & 1 & & \\
\hline $\begin{array}{l}7 \text { prefabricated } \\
\text { intention }\end{array}$ & 2,84 & 1,03 &, $33^{*}$ &, $56^{*}$ & ${ }_{*}^{3}, 37^{*}$ &, $35^{*}$ & ,09 & ${ }_{*}^{, 51} 1^{*}$ & 1 & \\
\hline $\begin{array}{l}8 \text { ready house } \\
\text { intention }\end{array}$ & 3,37 &, 87 &, $28^{*}$ & $40^{*}$ &, $29^{*}$ &, $31^{*}$ &, 18 &, $31^{*}$ & ${ }_{*} 47^{*}$ & 1 \\
\hline
\end{tabular}

**. Correlation is significant at the 0.01 level (2-tailed).

Table 4. Regression analysis

\begin{tabular}{lcccccc}
\hline \hline $\begin{array}{l}\text { Independent } \\
\text { variables }\end{array}$ & Std. Coeff. & Sig. & df & F-value & Sig & Adj. R sq. \\
\hline \hline (Constant) & &, 73 & 6 & 14,790 & 0,001 & 44 \\
investment tool &, 356 &, 00 & 96 & & & \\
flexibility &, 119 &, 19 & & & & \\
quality &, 127 &, 13 & & & & \\
efficiency &,- 173 &, 04 & & & & \\
appearance &, 320 &, 00 & & & & \\
marketing &, 080 &, 32 & & & & \\
communication & & &
\end{tabular}

Dependent Variable: prefabricated house using/buying intention 